\title{
Study of the relation between hydraulic jump and the flood water level in the river on the downstream of a spillway
}

\author{
Dwiva Anbiya Taruna ${ }^{1, *}$, Mohammad Bagus Adityawan ${ }^{1,2}$, Joko Nugroho ${ }^{1}$, Mohammad Farid ${ }^{1}$, Arno Adi Kuntoro $^{1,2}$, and \\ Widyaningtias ${ }^{1}$
}

${ }^{1}$ Water Resources Engineering Research Group, Faculty of Civil and Environmental Engineering, Institut Teknologi Bandung, Bandung, Indonesia

${ }^{2}$ Center for Water Resources Development, Institute for Research and Community Services, Institut Teknologi Bandung, Bandung, Indonesia

\begin{abstract}
Kuningan Dam which is located in Kuningan District, West Java has 21,8 km2 watershed area. This dam also acts as a flood control facility which functions supported by the reservoir's topography and its spillway building. The spillway building releases excess water from the dam into the downstream area. In the downstream part of the spillway, usually, hydraulic jump phenomenon occurs which depends on the flood water level of the river. The hydraulic jump used in the designing process of stilling basin length. The stilling basin in the spillway building generally designed using Q100. The spillway in Kuningan Dam is designed as a closed conduit channel. In this study, the Kuningan Dam spillway is re-designed as an open channel using ogee type spillway. Based on the modeling result, the length of hydraulic jump that occurs when modeled with the return period discharge of Q25 is $21.54 \mathrm{~m}, \mathrm{Q} 50$ is $16.65 \mathrm{~m}$, and Q100 is $0.98 \mathrm{~m}$. It is seen that in Q25 the jump was the furthest, so an elaborate study regarding hydraulic jump phenomenon and design standards of the spillway is required.
\end{abstract}

\section{Introduction}

Dam is a structure in the form of earth fill, rockfill, or concrete, built to gather water to form a reservoir [1]. Dam is a big structure with many benefits, but it also possesses high risks when dam breakage happens. Dam break is one of the most dangerous events, which causes flash flood disaster at the downstream area [2]. To prevent dam break, hydraulic structures, such as spillway, is used to regulate flood discharge.

In this study, Kuningan Dam spillway was re-designed using the ogee type and as an open channel. Ogee typeopen channel is commonly used in Indonesia. Therefore, redesigning the spillway leads to better practicability of this study. A spillway is a structure used to control the release of flows during a flood event from a dam into its downstream area. Spillway structure consists of a control structure, discharge channel, terminal structure, entrance, and outlet channels [3].

On the entrance and outlet channels, there is a structure called stilling basin that reduces the energy of water by forcing a hydraulic jump before its release to the downstream river. Hydraulic jump calculation has been studied widely. A One-Dimensional approach based on the St. Venant equation has been shown to perform well in the modeling of a hydraulic jump [4].
In Indonesia, a 100-year period for the design discharge is commonly used for designing stilling basin. In reality, the flood discharge could be lower than this design discharge. Nevertheless, the magnitude of the flood discharge will have a significant effect on the downstream area such as scouring. It has been shown that the hydraulic jump is an important factor in scouring [5]. However, a very high design discharge leads to a higher cost in construction of the structure. In order to determine the effective value of the design discharge, a study to model the river and stilling basin under various return period of flood discharge is needed. The modeling is conducted to observe the effect of different discharge magnitude flowing on a spillway and the corresponding flood water level in its downstream to the hydraulic jump.

\section{Location of the study}

Kuningan Dam is located in Randusari Village, Cibeureum District, Kuningan Regency, West Java Province, Indonesia. The dam is located on the Cikaro Riverflow (3rd order) which is a tributary of Cisanggarung River. Kuningan Dam was built to fulfill water supply for irrigation, raw water in the downstream area, and water supply for hydropower plant.

\footnotetext{
* Corresponding author: dwivaanbiya $@$ gmail.com
} 


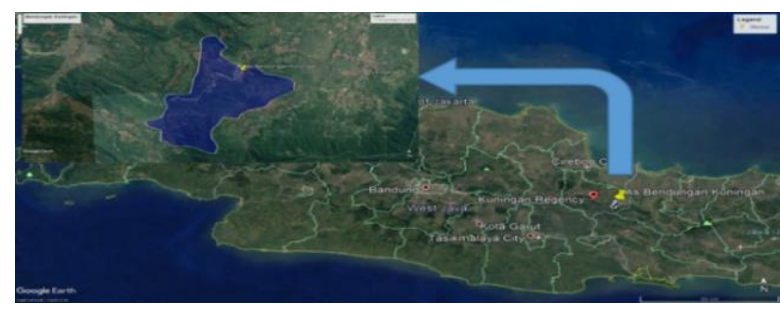

Fig. 1. Location of Kuningan Dam

Figure 2 shows the layout of Kuningan Dam which includes the redesigned spillway.

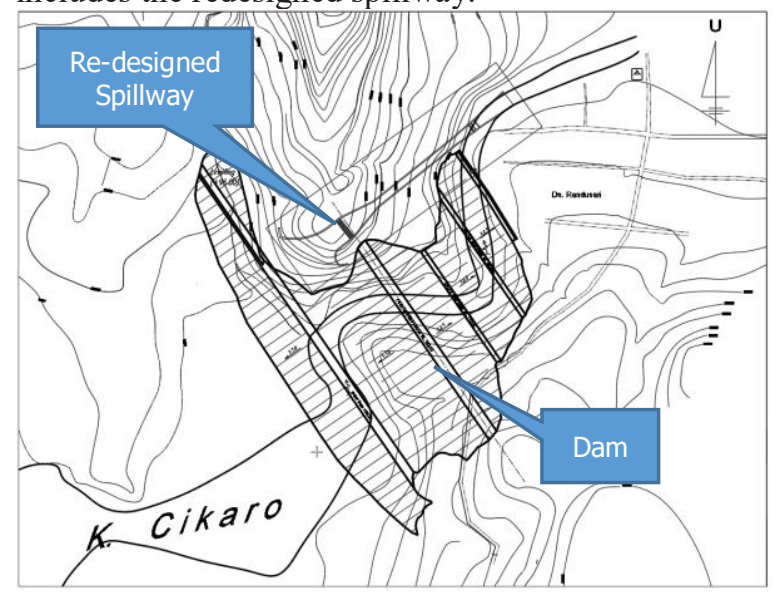

Fig. 2. Layout of Kuningan Dam

Kuningan Dam has the following storage capacity curve as shown in Figure 3.

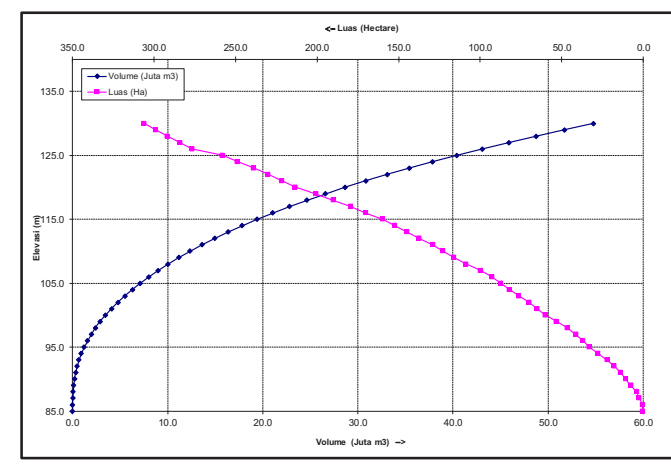

Fig. 3. Storage Capacity Curve of Kuningan dam Source: BBWS Cimanuk-Cisanggarung, 2013

\section{Methodology}

The methodology of the study shown in the following flow chart in Figure 4.

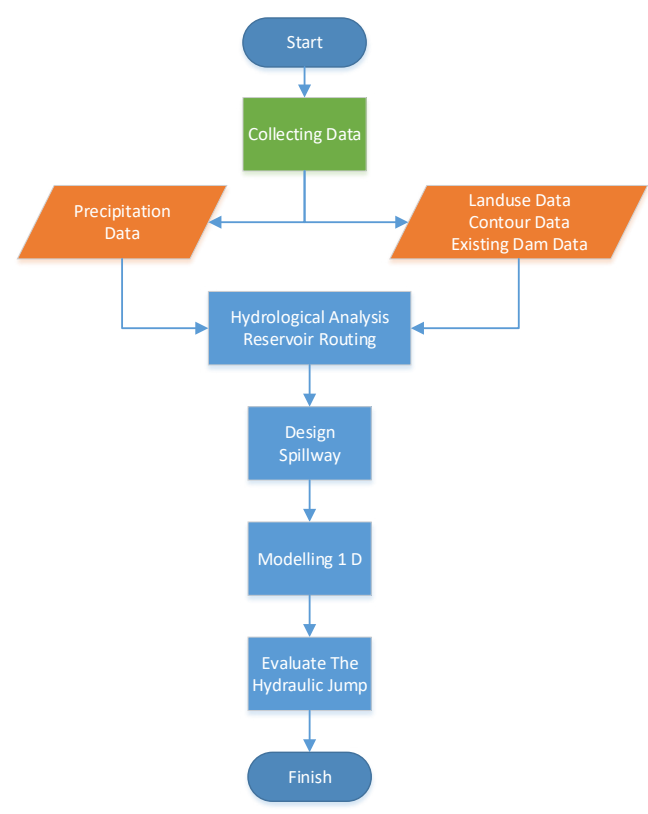

Fig. 4 Methodology of the study

Relevant data were collected. They are precipitation, land use, topograhpy, and data of the dam. Hydrological analysis were conducted including watershed analysis, design precipitation, and flood hydrograph. In the watershed analysis, runoff factor is determined based on topography and land use data from Badan Informasi Geografis (BIG). Statistical analysis was conducted to obtain daily maximum precipitation for various return periods. The flood discharge of the watershed is estimated using Nakayashu Method. The outflow discharge is estimated by calculating the reservoir routing using HECHMS.

The outflow discharge is used to design the spillway dimension. This design is modelled using a one dimensional steady flow approach in HEC-RAS. The simulations were conducted for 3 design flood discharge with the return period of 100-year, 50-year, and 25-year. The results were analysed to assess the relation between hydraulic jump lengths and flood water level of the spillway downstream area.

\section{Hydrological analysis}

\subsection{Watershed analysis}

Kuningan Dam is located in Kuningan District, West Java, Indonesia and has $21.8 \mathrm{~km}^{2}$ watershed area. The dam connected to Cikaro River. The length of the river from the upstream to the dam outlet approximately is about $7.38 \mathrm{~km}$ with average slope of $0.2 \%$. Figure 5 shows Kuningan Dam watershed area 


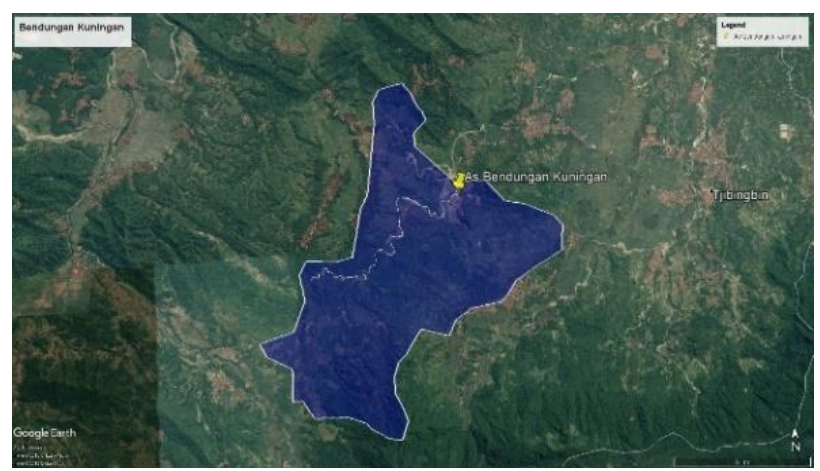

Fig. 5. Kuningan Dam Watershed

Source: Google Earth, 2018

Land use of the Kuningan Dam watershed area is dominated by production forest $(27.31 \%)$, animal husbandry $(22.26 \%)$, irrigated rice fields $(17.81 \%)$, and protected areas $(11.87 \%)$.

\subsection{Data availability}

In the watershed area of Kuningan Dam, there are two rain stations owned by Badan Meteorologi, Klimatologi, dan Geofisika (BMKG) which are Cibingbin and Ciwaru Station. To make flood hydrograph, it requires at least precipitation data of 10 years [6]. Precipitation data of Kuningan Dam watershed area from 1991 to 2010 is available.

\subsection{Design precipitation}

First, the precipitation area is anaylzed using Thiessen method. Then the frequency analysis is done using three different methods, Gumbel, Normal, and Log Person III. The frequency analysis then followed by chi-square and Smirnov Kolmogorov test.

Table 1. Recapitulation of design precipitation plan

\begin{tabular}{|c|c|c|c|c|}
\hline \multirow{3}{*}{ No. } & $\begin{array}{l}\text { Return } \\
\text { Period }\end{array}$ & \multicolumn{3}{|c|}{ Design Rainfall Plan ( mm ) } \\
\hline & \multirow[b]{2}{*}{ (Year) } & \multicolumn{3}{|c|}{ Method } \\
\hline & & Gumbel & Normal & $\begin{array}{c}\text { Log } \\
\text { Pearson } \\
\text { Type III }\end{array}$ \\
\hline 1 & 25 & 129.64 & 113.04 & 113.65 \\
\hline 2 & 50 & 143.26 & 120.03 & 118.46 \\
\hline 3 & 100 & 156.78 & 125.79 & 128.49 \\
\hline \multicolumn{5}{|c|}{ SMIRNOV KOLMOGOROV TEST } \\
\hline $\mathrm{D} \mathrm{Ma}$ & num & 0.046 & 0.002 & 0.004 \\
\hline $\begin{array}{l}\text { Degre } \\
\text { signif }\end{array}$ & & $5 \%$ & $5 \%$ & $5 \%$ \\
\hline $\mathrm{DCri}$ & & 0.290 & 0.290 & 0.290 \\
\hline Status & & PASS & PASS & PASS \\
\hline \multicolumn{5}{|c|}{ CHI SQUARE TEST } \\
\hline \multicolumn{2}{|c|}{ Chi Square Count } & 7.600 & 10.000 & 1.067 \\
\hline \multicolumn{2}{|c|}{$\begin{array}{l}\text { Chi Square } \\
\text { Critical }\end{array}$} & 7.815 & 7.815 & 7.815 \\
\hline \multicolumn{2}{|c|}{ Free degree } & 3.000 & 3.000 & 3.000 \\
\hline \multicolumn{2}{|c|}{$\begin{array}{l}\text { Degree of } \\
\text { significance }\end{array}$} & $5 \%$ & $5 \%$ & $5 \%$ \\
\hline \multicolumn{2}{|c|}{ Status } & PASS & $\begin{array}{l}\text { NOT } \\
\text { PASS }\end{array}$ & PASS \\
\hline
\end{tabular}

From the analysis shown in Table 1, the selected precipitation design value is the one using Gumbel method. After the precipitation value is determined, distribute the precipitation value with Mononobe Method [7].

Precipitation duration used in the designing process is 6 hours. From the duration, the scheme of the precipitation distribution is made as shown in Figure 6.

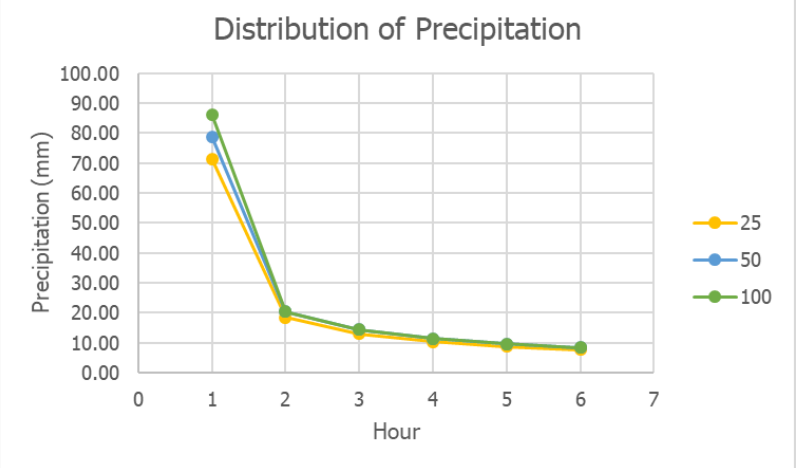

Fig. 6. Distribution of precipitation by Mononobe method

\subsection{Flood hydrograph}

Flood hydrograph used in this study is the Nakayasu model. The model is calculated using the data obtained from 6-hours distributed precipitation data.

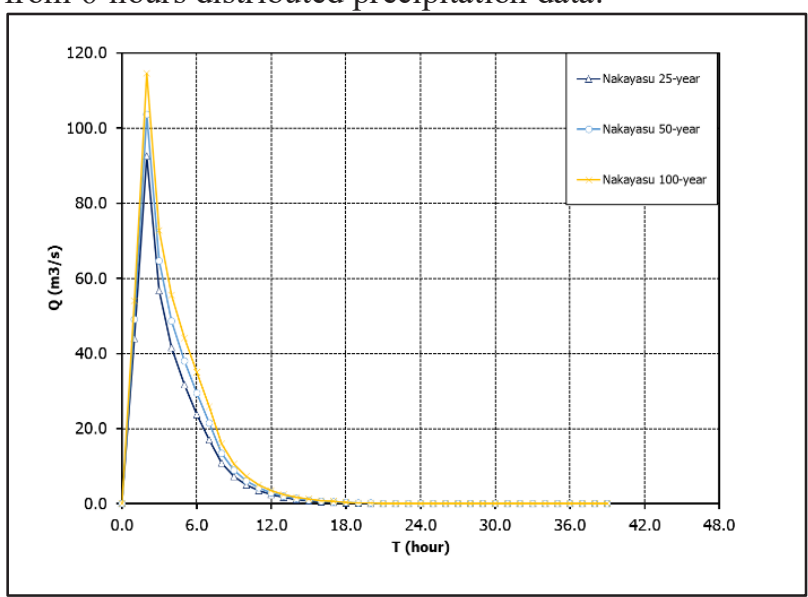

Fig. 7. Nakayasu model flood hydrograph (Q25, Q50, and Q100 year)

Table 2 shows the peak discharge of each flood hydrographs.

Table 2. Peak Discharge of designed flood hydrograph

\begin{tabular}{|c|c|}
\hline $\begin{array}{c}\text { Return Period } \\
\text { (year) }\end{array}$ & $\begin{array}{c}\text { Peak Discharge } \\
\text { (m3/s) }\end{array}$ \\
\hline 25 & 92.53 \\
\hline 50 & 103.60 \\
\hline 100 & 114.59 \\
\hline
\end{tabular}

\subsection{Reservoir Routing}

Reservoir routing is calculated and modeled using HECHMS program. The calculation use the following storage method equation 


$$
\left(I_{n}+I_{n+1}\right)+\left(\frac{2 S_{n}}{\Delta t}-Q_{n}\right)=\left(\frac{2 S_{n+1}}{\Delta t}+Q_{n+1}\right)
$$

Where :

$$
\begin{aligned}
\mathrm{I} & =\text { inflow }\left(\mathrm{m}^{3} / \mathrm{s}\right) \\
\mathrm{S} & =\text { storage }\left(\mathrm{m}^{3}\right) \\
\mathrm{Q} & =\text { outflow }\left(\mathrm{m}^{3} / \mathrm{s}\right)
\end{aligned}
$$

Inflow used in the equation is the value of flood hydrograph inflow and the re-designed spillway. From the calculation the following value are determined. Weir discharge coefficient $(\mathrm{C})$ is 2.15 , design head $(\mathrm{H})$ is 2.6 $\mathrm{m}$, approach channel depth $(\mathrm{P})$ is $3 \mathrm{~m}$, and weir width (L) is $20 \mathrm{~m}$. The results of reservoir routing by each flood hydrograph design is shown in Figure 8.

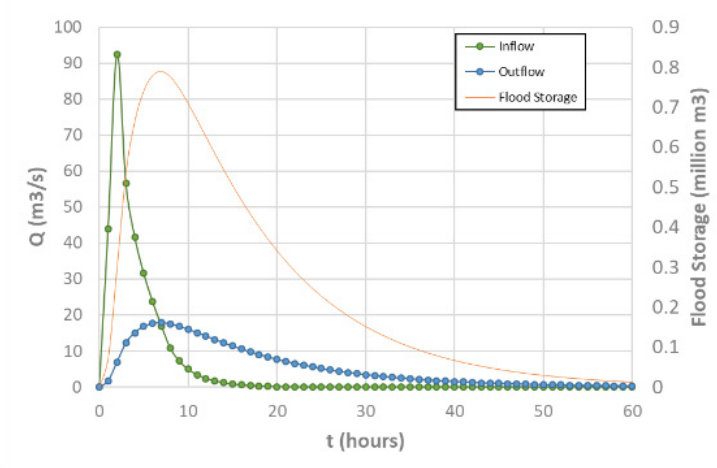

(a)

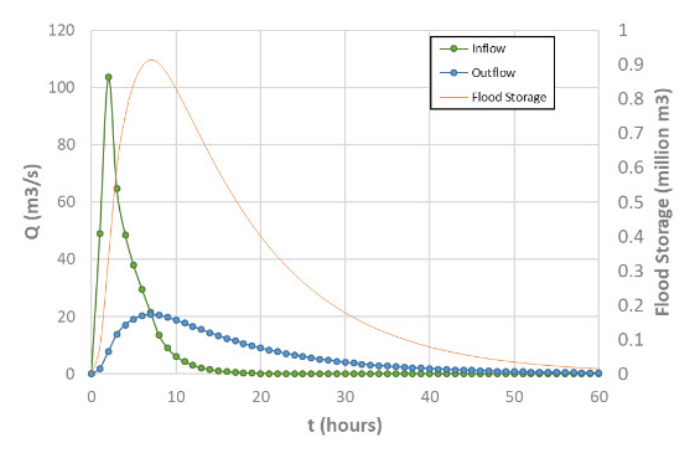

(b)

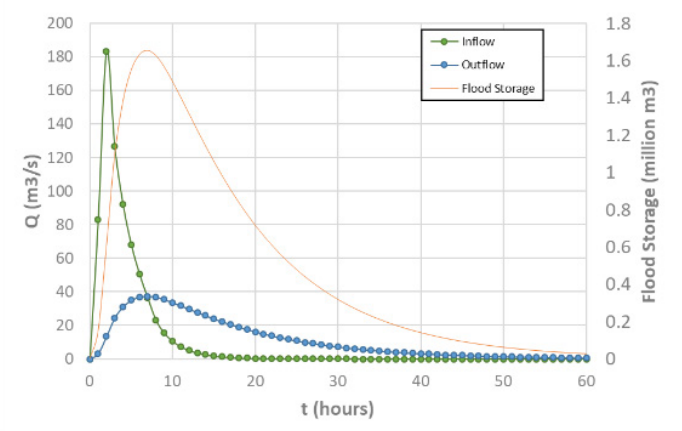

(c)

Fig. 8 Result of reservoir routing of each inflow flood hydrograph (a) Return period 25-year, (b) Return period 50year, and (c) Return Period 100-year.

Table 3 shows the peak discharge of inflow-outflow for each flood hydrographs.
Table 3. Inflow-outflow peak discharge of reservoir routing

\begin{tabular}{|c|c|c|}
\hline $\begin{array}{c}\text { Return Period } \\
\text { (year) }\end{array}$ & $\begin{array}{c}\text { Inflow Peak } \\
\text { Discharge (m3/s) }\end{array}$ & $\begin{array}{c}\text { Outflow Peak } \\
\text { Discharge (m3/s) }\end{array}$ \\
\hline 25 & 92.53 & 17.87 \\
\hline 50 & 103.60 & 20.68 \\
\hline 100 & 114.59 & 23.46 \\
\hline
\end{tabular}

\section{One-dimensional flood modeling}

One-dimensional model of the spillway is made using HEC-RAS. A program that is commonly used for hydraulic analysis, HEC-RAS is also used for laboratoryscale simulations of a Single Step Weir [8].

\subsection{Basic simulation}

HEC-RAS is capable of performing one-dimensional water surface profile calculations for steady gradually varied flow in natural or constructed channels. Equation for basic profile calculations is written as follows:

$$
Z_{2}+Y_{2}+\frac{a_{2} V_{2}^{2}}{2 g}=Z_{1}+Y_{1}+\frac{a_{1} V_{1}^{2}}{2 g}+h_{e}
$$

Where :

$Z_{1}, Z_{2}=$ elevation of the main channel inverts

$Y_{1}, Y_{2}=$ depth of water at cross sections

$V_{1}, V_{2}=$ average velocities (total discharge/total flow area)

$a_{1}, a_{2}=$ velocity weighting coefficients

$\mathrm{g}=$ gravitational acceleration

$h_{\mathrm{e}} \quad=$ energy head loss

The energy head loss $\left(h_{\mathrm{e}}\right)$ between two cross sections is comprised caused by friction losses and contraction or expansion losses. The equation for the energy head loss is written as follows :

Where :

$$
h_{e}=L \bar{S}_{f}+C\left|\frac{a_{2} V_{2}^{2}}{2 g}-\frac{a_{1} V_{1}^{2}}{2 g}\right|
$$

$$
\begin{aligned}
\mathrm{L} & =\text { discharge weighted reach length } \\
\bar{S}_{f} \quad= & \text { representative friction slope between two } \\
& \text { sections } \\
C \quad= & \text { expansion or contraction loss coefficient }
\end{aligned}
$$

\begin{tabular}{|c|c|c|c|c|c|}
\hline \multicolumn{2}{|c|}{ Component Name } & $\begin{array}{c}\text { Length } \\
\text { (m) }\end{array}$ & $\begin{array}{c}\text { Width } \\
\text { (m) }\end{array}$ & $\begin{array}{c}\text { Base } \\
\text { Elevation }\end{array}$ & Slope \\
\hline \multirow{2}{*}{$\begin{array}{l}\text { Approach } \\
\text { Channel }\end{array}$} & U.S. & \multirow{2}{*}{20.00} & \multirow{2}{*}{20} & \multirow{2}{*}{115.00} & \multirow{2}{*}{0} \\
\hline & D.S. & & & & \\
\hline \multirow{2}{*}{$\begin{array}{c}\text { Weir of } \\
\text { Spillway }\end{array}$} & U.S. & \multirow{2}{*}{4.69} & \multirow{2}{*}{20} & 118.00 & \multirow{2}{*}{$\begin{array}{l}\text { Harold } \\
\text { Arch }\end{array}$} \\
\hline & D.S. & & & 115.00 & \\
\hline \multirow{2}{*}{$\begin{array}{c}\text { Transition } \\
\text { Channel }\end{array}$} & U.S. & \multirow{2}{*}{33.00} & 20 & 115.00 & \multirow{2}{*}{0.20} \\
\hline & D.S. & & 5.50 & 108.40 & \\
\hline \multirow{2}{*}{$\begin{array}{l}\text { Chute } \\
\text { Channel }\end{array}$} & U.S. & \multirow{2}{*}{90.00} & \multirow{2}{*}{5.50} & 108.40 & \multirow{2}{*}{0.30} \\
\hline & D.S. & & & 81.40 & \\
\hline \multirow{2}{*}{$\begin{array}{l}\text { Trumpet } \\
\text { Channel }\end{array}$} & U.S. & \multirow{2}{*}{20.00} & 5.50 & 81.40 & \multirow{2}{*}{0.15} \\
\hline & D.S. & & 7.50 & 78.40 & \\
\hline
\end{tabular}

\subsection{Parameter input}

Data from the redesigned spillway is calculated as shown in Table 4 to determine the dimension of each spillway parts.

Table 4. Technical data of spillway 


\begin{tabular}{|c|c|c|c|c|c|}
\hline \multicolumn{2}{|c|}{ Component Name } & $\begin{array}{c}\text { Length } \\
\text { (m) }\end{array}$ & $\begin{array}{c}\text { Width } \\
\text { (m) }\end{array}$ & $\begin{array}{c}\text { Base } \\
\text { Elevation }\end{array}$ & Slope \\
\hline \multirow{2}{*}{$\begin{array}{l}\text { Stilling } \\
\text { Basin }\end{array}$} & U.S. & \multirow{2}{*}{4.00} & \multirow{2}{*}{7.50} & \multirow{2}{*}{78.40} & \multirow{2}{*}{0} \\
\hline & D.S. & & & & \\
\hline \multirow{2}{*}{$\begin{array}{l}\text { End } \\
\text { Channel }\end{array}$} & U.S. & \multirow{2}{*}{36.00} & 7.50 & 78.70 & \multirow{2}{*}{0.001} \\
\hline & D.S. & & 14.00 & 78.66 & \\
\hline
\end{tabular}

After the calculation, input the steady flow using the peak discharge value of each flood hydrograph design which based on the result of reservoir routing (outflow peak discharge). For the reach boundary condition, input the upstream and downstream boundary and its water surface level. The upstream water surface level based on the calculation of the water level in upstream section meanwhile the downstream level is based on normal water level of the river.
Table 5. Boundaries' Water surface level

\begin{tabular}{|c|c|c|}
\hline \multirow{2}{*}{$\begin{array}{c}\text { Return Period } \\
\text { (year) }\end{array}$} & \multicolumn{2}{|c|}{ Known WS (m) } \\
\cline { 2 - 3 } & Upstream & Downstream \\
\hline 25 & 118.42 & 80.15 \\
\hline 50 & 118.48 & 80.28 \\
\hline 100 & 118.55 & 80.41 \\
\hline
\end{tabular}

At last, set up the simulation by choosing geometric data, steady flow data with the reach boundary condition, and lastly choose the flow regime which in this study is mixed flow regime.

\subsection{Simulation results}

The results of the simulation using HEC-RAS is presented in Figure 13 below.

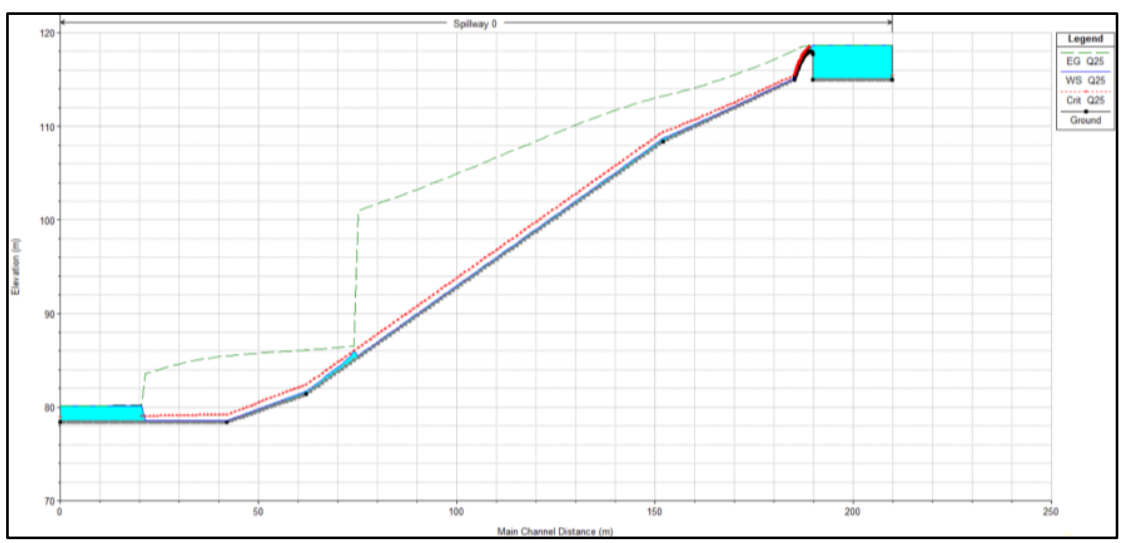

(a)

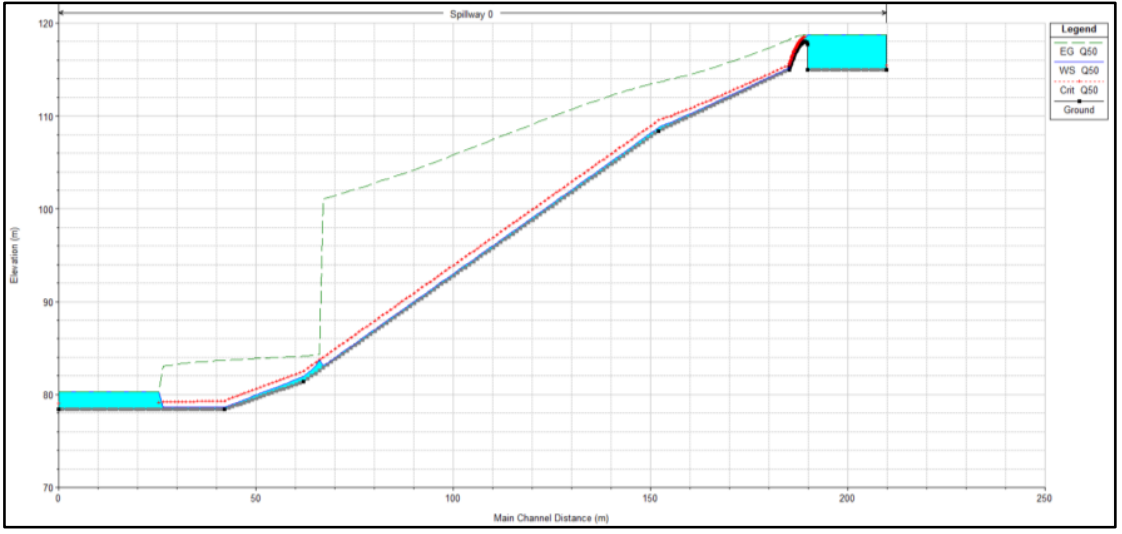

(b)

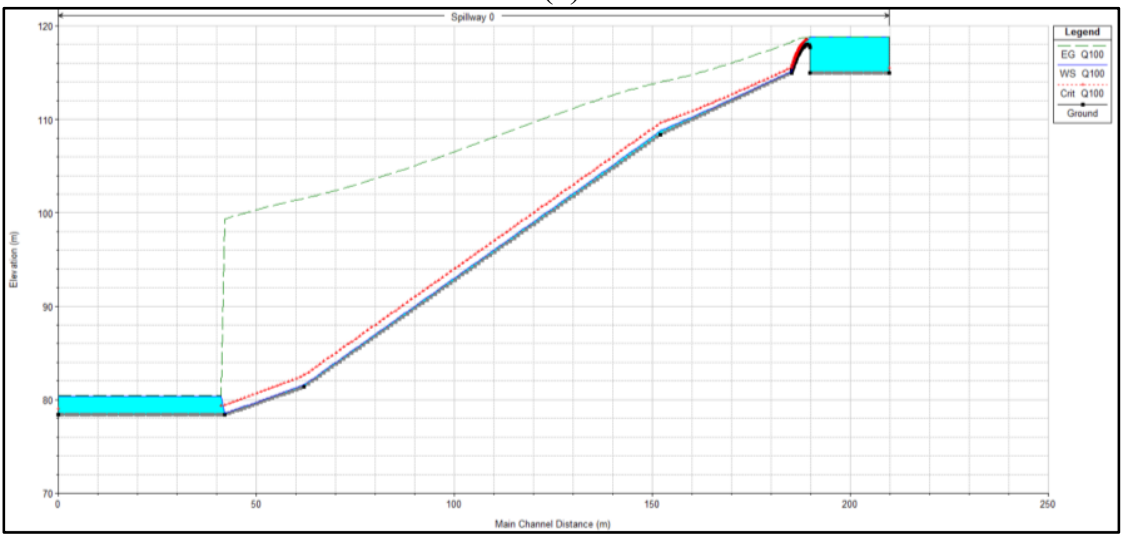

(c)

Fig. 9 One-dimensional modeling of each flood hydrograph (outflow) (a) Return period 25-year, (b) 50-year, and (c) 100-year. 


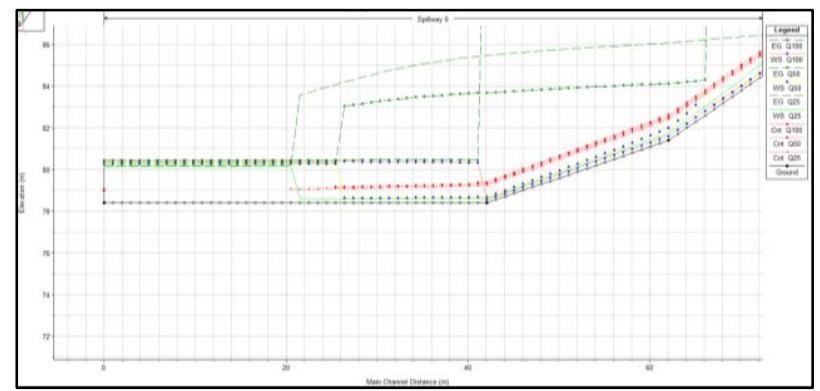

Fig. 10 One-dimensional modeling for each flood hydrograph (outflow) with return period of 100-year, 50-year, and 25-year.

Table 6 shows the condition of flow and length of hydraulic jump for each flood hydrograph.

Table 6. Condition of flow before and after hydraulic jump

\begin{tabular}{|c|c|c|c|c|c|}
\hline \multirow{2}{*}{$\begin{array}{c}\text { Retur } \\
\text { n } \\
\text { Period } \\
\text { (Year) }\end{array}$} & \multicolumn{4}{|c|}{ Condition of Flow } & \multirow{2}{*}{$\begin{array}{l}\text { Length of } \\
\text { Hydrauli } \\
\text { c Jump } \\
\text { (m) }\end{array}$} \\
\hline & $\begin{array}{c}\text { y1 } \\
\text { (m) }\end{array}$ & Fr1 & $\begin{array}{c}\text { y2 } \\
\text { (m) }\end{array}$ & Fr2 & \\
\hline 25 & 0.21 & 8.39 & 1.75 & 0.23 & 21.54 \\
\hline 50 & 0.28 & 6.31 & 1.88 & 0.26 & 16.65 \\
\hline 100 & 0.15 & 16.39 & 2.01 & 0.36 & 0.98 \\
\hline
\end{tabular}

\section{Conclusion}

The results from this study conclude that the length of hydraulic jump for return period discharge of 25-year is longer than the one from 100-year. If the jump is longer from the designed flood discharge $(\mathrm{T}=100$-year $)$, it may damage the river system in the downstream. Therefore, the design code of the designed flood for the stilling basin must be evaluated.

This study only shows the simulation in a onedimensional direction. Thus, the results obtained from this study is limited to a certain condition. To get more accurate results, further study should be conducted using an unsteady flow condition in two-dimensional or threedimensional.

This research is supported by the Program Penelitian, Pengabdian kepada Masyarakat, dan Inovasi (P3MI), Institut Teknologi Bandung.

\section{References}

1. Badan Standardisasi Nasional, SNI 8062:2015 Tata cara desain tubuh bendungan tipe urugan (2015)

2. M. Farid, B. P. Yakti, A. Rizaldi, M. B. Adityawan, Finite Difference Numerical Scheme for Simulating Dam Break Flow, The 5th HATHI International Seminar on Water Resilience in a Changing World, 1, (2016)

3. U.S. Department of The Interior, Design of Small Dams, 339, (2012)

4. N. L. H. Zendrato, A. Chrysanti, B. P. Yakti, M. B. Adityawan, Widyaningtias, Y. Suryadi, Application of
Finite Difference Schemes to $1 D$ St. Venant for Simulating Weir Overflow, The Third International Conference on Sustainable Infrastructure and Built Environment (SIBE) 2017, MATEC Web of Conferences, 5-6, (2018)

5. Y. Mitobe, M. B. Adityawan, H. Tanaka, T. Kawahara, T. Kurosawa, K. Otsushi, Experiments On Local Scour Behind Coastal Dikes Induced By Tsunami Overflow, Coastal Engineering Proceedings 1(34):62, 1-8, (2014)

6. Badan Standardisasi Nasional, SNI 2415:2016 Tata cara perhitungan debit banjir rencana (2016)

7. F. Asfa., Y. L. Handayani, A. Hendri., Pola Distribusi Hujan Jam-Jaman pada Stasiun Hujan Pasar Kampar, Jom FTEKNIK Volume 1 No. 2, 5, (2014)

8. J. M. Fariq, Laboratory and HEC-RAS Simulations of a Single-Step Weir, ARPN Journal of Engineering and Applied Sciences, 6-10, (2013) 